\title{
Firms' main market, human capital, and wages
}

\author{
Francisco Alcalá • Pedro J. Hernández
}

Received: 2 October 2008/Accepted: 9 October 2009/Published online: 8 January 2010

(C) Spanish Economic Association and Fundación SEPI 2010

\begin{abstract}
The literature on the exporter wage premium has focused on an exporter/non-exporter dichotomy. Instead, this paper provides first evidence that there is a more continuous destination-market effect. Using Spanish data, we estimate wage premia for establishments selling to the national, European Union, and rest of the world markets (with respect to wages in local-market establishments). Controlling for worker and establishment characteristics, output-market wage premia are increasing in market remoteness and employee education. Establishment human capital is also increasing in output-market remoteness. The paper builds a theoretical model that provides a potential explanation for these empirical results, which is also consistent with the recent evidence on the positive relationship between output-market remoteness and quality of exports.
\end{abstract}

Keywords Wage inequality · International trade - Alchian-Allen effect · Vertical differentiation

JEL Classification $\mathrm{F} 16 \cdot \mathrm{J} 24 \cdot \mathrm{J} 31$

\author{
F. Alcalá $(\bowtie)$ \\ Facultad de Economia y Empresa, Universidad de Murcia, \\ Campus de Espinardo, 30100 Murcia, Spain \\ e-mail: falcala@um.es \\ F. Alcalá \\ IVIE, Valencia, Spain \\ P. J. Hernández \\ Universidad de Murcia, Murcia, Spain \\ e-mail: nani@um.es
}




\section{Introduction}

This paper contributes to the recent literature on the exporter wage premium. This literature has focused on an exporter/non-exporter dichotomy. Instead, this paper provides first evidence that there is a more continuous destination-market effect. Using Spanish data, we estimate wage premia for establishments selling to the national, European Union, and rest of the world markets (with wages in localmarket establishments as the reference). Controlling for worker and other establishment characteristics, we find all these output-market wage premia significant and increasing in market remoteness and employee education. We also find that establishments' human capital is increasing in the remoteness of their main output market. On the theoretical side, we build a model predicting that firms selling to more-remote markets employ higher human capital, pay higher wages to employees within each education group, and produce higher quality. The model provides a potential explanation for our empirical results, which is consistent with the evidence on the relationship between destination-market remoteness and quality of exports put forward by recent trade literature.

The literature on the exporter wage premium was initiated by Bernard and Jensen (1995). Using plant level data from US manufacturing, they showed that exporters pay higher wages. Their approach was to regress average wage in a plant on plant characteristics (size, sector, etc.) and on a dummy for export status. This approach has been repeated for many different countries (see Schank et al. (2007) for a review). However, almost all these studies use plant level data and therefore do not control for worker characteristics. As a result, they cannot really check if similar workers are paid higher wages in exporting firms and how the exporter premium, if any, depends on individuals' education. Moreover, all of the literature draws a single sharp dichotomy between exporters and non-exporters. However, it is unclear whether such a sharp dichotomy exists, as opposed to a more continuous outputmarket effect that is increasing in market distance and that may work even within national borders.

Two recent papers are able to estimate the exporter wage premium controlling for worker characteristics. Schank et al. (2007) and Munch and Skaksen (2008) use matched plant-worker data for Germany and Denmark, respectively, and find a significant positive wage effect of firm export intensity, even after controlling for worker education. In this paper we extend this evidence using Spanish matched data for more than 15,000 establishments and 150,000 employees from the Encuesta de Estructura Salarial (Survey on the Wage Structure). Our results confirm the existence of an exporter wage premium after controlling for individual characteristics of workers. However, our quantitative results show important differences from these two papers. Schank et al. (2007) find that the exporting wage premium almost vanishes when worker characteristics are controlled for. Munch and Skaksen (2008) find that the level of firms' export intensity is not significant when an interaction between this and firm skill intensity is included. They conclude that the export premium only accrues to firms with high human capital. In contrast, we find a significant exporter wage premium that is still larger than $10 \%$ after controlling for worker and other firm observable characteristics. When including an interaction 
term with firm's human capital, the coefficient on the export status remains almost unchanged whereas the interaction term coefficient is almost zero and insignificant. On the issue of how the exporter premium relates to individual characteristics, Schank et al. (2007) find that the premium is larger for blue-collar than for whitecollar employees, whereas Munch and Skaksen (2008) find no monotone relationship between the premium and education. ${ }^{1}$ In this paper we find that all output-market wage premia in Spain are monotonically increasing in education (as well as the establishment's human capital wage premium). As we discuss in the corresponding section, disparities between our results and those in these papers may be due to differences in the type of data, estimation techniques, and differences between the Spanish economy and the German and Danish economies.

Still, the most novel empirical contribution of this paper is to show that instead of a single exporter/non-exporter dichotomy with respect to wages and human capital, there is a more continuous destination-market effect. We find that employees in national-market establishments obtain wages $10.5 \%$ higher than employees with the same observable characteristics in local-market establishments. This wage premium rises to $17.0 \%$ if the establishment's main market is the European Union, and to $21.9 \%$ if the main market is the rest of the world (always using as reference wages in firms whose main market is a local one). With respect to human capital, we find that the proportion of college graduates in national-market establishments is $5.6 \%$ points higher than in local-market establishments. This proportion is 9 points higher in establishments whose main market is the European Union, and 12.9 points higher in establishments whose main market is the rest of the world. ${ }^{2}$

We also jointly estimate firm size and coworkers' average education effects on wages. ${ }^{3}$ Overall, estimated firm-characteristics wage effects are substantial and provide important patterns of wage inequality within education groups. For example, the estimated wage of a college graduate working in an establishment with favorable characteristics (i.e., a large exporter with average employee education in the forth quintile of the distribution) almost doubles the wage of an individual with the same observable personal attributes who works in an establishment with unfavorable characteristics (i.e., a small local-market establishment with coworkers' education in the first quintile of the distribution). Our results also suggest that increasing globalization may play a significant role in raising wage inequality across education groups. Note in this respect that firm output-market wage effects for

\footnotetext{
${ }^{1}$ In fact, these authors find a larger premium for vocational-education workers than for workers with further education whose premium is almost not significant.

${ }^{2}$ Even the specific impact of exporting on establishment human capital is not well documented. Existing studies use data sets that do not contain information on individual workers' education. As a result, analyses tend to rely on data distinguishing between blue-collar workers and white-collar workers, or on information about occupations. See Bernard and Jensen (1997), (1999), Maurin et al. (2002), Biscourp and Kramarz (2007), and Bernard et al. (2007).

3 The existence of a positive firm-size wage premium has been extensively documented. See Idson and Oi (1999), Troske (1999), among others. Lallemand et al. (2005) provide reviews of empirical results and theoretical arguments. There is also an empirical literature pointing out the effect of average coworkers' education upon individual wages. See Bayard and Troske (1999), Troske (1999), Battu et al. (2003), and Alcalá and Hernández (2006).
} 
college graduates triple those for individuals that did not complete secondary studies.

Previous papers on the exporter wage premium provide some informal possible explanations for this effect. In the second part of this paper, we build a partial equilibrium model that provides a potential joint explanation for all our empirical results. The model has the important virtue of being consistent with some notable facts recently documented by the international trade literature. This literature makes clear the importance of introducing firm heterogeneity and quality differentiation in models of exports. In our model, efficiency-heterogeneous firms in terms of their efficiency optimally choose output quantity and quality, destination markets, and employees' composition in terms of education and unmeasured skills. In equilibrium, more-efficient firms are larger, produce higher quality, sell in more-remote markets and employ a larger share of workers with high education and skills. As a result, the model predicts a positive link at the firm level between size, remoteness of output markets, human capital, and average wages paid within each education group. 4

The facts and arguments in the recent trade literature with which our model is consistent can be summarized as follows. Firm heterogeneity is a prominent phenomenon that translates into substantial differences in export participation and number of output-markets across firms (see Eaton et al. (2004, 2008); for a survey of this fast growing literature, see Bernard et al. (2007)). Furthermore, describing the current patterns of trade requires considering quality differentiation. International trade is decreasingly characterized by horizontal specialization across goods and increasingly characterized by quality specialization within goods (see Schott (2004); Hummels and Klenow (2005); Khandelwal (2007); and Fontagne et al. (2008) among others). In this context, Hummels and Skiba (2004) have documented a positive relationship between export quality and transportation costs to destination market, in line with the well-known Alchian-Allen effect. Baldwin and Harrigan (2007) and Johnson (2007) provide evidence in the same direction. ${ }^{5}$ In particular, Baldwin and Harrigan (2007) find that unit prices of exports tend to increase with the remoteness of destination markets. They also show that previous standard firmheterogeneous trade models without quality differentiation are inconsistent with this evidence. The reason is that more-efficient firms sell at lower (fob) prices in all markets; since only the more-efficient firms sell in the more-distant markets, moredistant markets should have lower average import (fob) prices. They argue that introducing quality differentiation seems to be the most plausible way to rebuild previous models in order to make them consistent with the new evidence. Specifically, the link between firm efficiency and output quality can explain the larger export prices to more-distant markets. This same firm-efficiency/outputquality link is the mechanism used in this paper's model to explain the relationship

\footnotetext{
${ }^{4}$ Causality in the model runs from firm efficiency to export status. The reverse mechanism has also been suggested: being an exporter may increase efficiency. Recent evidence supports the first mechanism: see Schank et al. 2008.

5 Verhoogen (2008) also finds related evidence at the plant level of a positive relationship between exports and quality. Using a direct measure of quality (ISO 9000 certification), he finds that currency devaluation in Mexico induced the more-productive plants to upgrade output quality and to raise exports.
} 
between firm wages and human capital, on the one hand, and output-market remoteness on the other hand.

All the models cited above assume homogeneous labor within each country and therefore do not explore the possible links between firm's human capital, wages, quality, and remoteness of output markets. ${ }^{6}$ The model in this paper introduces heterogeneous labor and explains why firms selling in more-remote markets employ more human capital and pay higher wages in a manner that is consistent with the evidence and analysis in Hummels and Skiba (2004), Baldwin and Harrigan (2007), and Johnson (2007). Manasse and Turrini (2001), Yeaple (2005), and Verhoogen (2008) also provide models considering heterogeneous firms, heterogeneous labor, and exporting decisions. However, the differences between these models and the model in this paper are significant. In Manasse and Turrini (2001) there are heterogeneous skilled workers and homogeneous unskilled workers. Each firm employs only one skilled worker and a variable number of unskilled workers. The skilled worker is then most naturally interpreted as the entrepreneur and her specific skills are what make firms heterogeneous. Moreover, there is not an analysis of the optimal choice of output quality by the firm but an exogenous one-to-one correspondence between entrepreneur's skill and firm's output quality. Yeaple (2005) considers an economy with different available technologies leading to endogenously heterogeneous firms. In equilibrium, exporters are larger and employ more-skilled workers. However, he does not consider quality differentiated goods. Therefore, as explained before, it is unlikely that this model could be consistent with the facts documented in Hummels and Skiba (2004), Baldwin and Harrigan (2007), and Johnson (2007). Verhoogen (2008) lays out a model with both labor heterogeneity and quality differentiation, which is closest to ours. A key difference is that in Verhoogen (2008) there is no substitutability between workers with different skills as the firm raises output quality. Instead, producing one unit of output always requires one unit of blue-collar and one unit of white-collar labor. Then, the only way to produce higher quality is by increasing the quality (i.e., effort or skills) of these two units of labor. ${ }^{7}$ The model here provides a more general and plausible technology setting. There are also considerable differences between our model and the usual analysis of firms' self-selection as exporters to different markets, which will be discussed below.

The paper is organized as follows Sect. 2 explains the details of the data set. Section 3 explores the relationship between establishments' main market and human capital. Section 4 analyses the relationship between establishments' characteristics (such as main output market, size, and human capital) and individual wages. Section 5 provides a theoretical model that is consistent with the empirical results here and with important facts and regularities documented by the recent trade literature. Section 6 summarizes and concludes.

\footnotetext{
6 The same happens with general equilibrium models of trade with quality differentiation. See Flam and Helpman (1987), Falvey and Kierzkowski (1987), Stokey (1991), and Murphy and Shleifer (1997).

7 See also Hallak and Sivadasan (2008) for a model with two-dimensional firm heterogeneity which mostly follows Verhoogen (2008) on the specification of labor heterogeneity.
} 


\section{Data and descriptive statistics}

Our empirical analysis is based on data from the Spanish Encuesta de Estructura Salarial for 2002 (Wage Structure Survey, EES-2002). This survey contains matched employer-employee data for more than 15,000 employers and 150,000 employees. It is conducted by the Spanish National Institute of Statistics following a two-stage stratified sampling methodology. In the first stage, establishments with at least ten workers are stratified by economic activity, firm size and region. Agriculture and the public sector are excluded. In the second stage, workers at every establishment are randomly selected. The survey provides information about the region where the establishment is located, industry, size, collective bargaining if any, and main broad destination market for output. The main destination market attribute distinguishes between local, national, European Union and rest of the world markets. In our analysis, we exclude from the sample industries that do not have any exporting establishment (building, production and distribution of electrical energy, gas and water, education, health, social work and other social activities, and personal service activities). This leaves a sample of 11,567 establishments from 36 three-digit industries (main subsections of the National Classification of Economic Activities).

The survey also provides information on the main individual characteristics of workers randomly selected at every establishment, such as education, sex, age, years working in the current establishment, type of contract, full/part-time job, etc. In our analysis on wages, we restrict the sample to male workers with full-time jobs and indefinite contracts. ${ }^{8}$ We also exclude workers who went through transitory labor incapacity or were included in job promotion programs. In this way, we isolate the establishment-characteristic effects on wages from other circumstances such as gender discrimination, positive discrimination policies, underemployment, etc. This depuration brings about a sample of 35,602 workers and 9,120 establishments.

Table 1 reports the main descriptive statistics on establishment characteristics. As in other countries, establishments whose main market is exports are only a small fraction of the total (about 6.5\%). Most establishments have less than 50 workers (71.3\%) and only $11 \%$ employ 200 or more workers. Although the percentage of workers with a college degree is 10.5 , only $27.6 \%$ of the establishments in the sample include at least one worker with a college degree among their surveyed employees. The percentage of workers with a college degree in this last subset of establishments is 34.2. This suggests that the data on the fraction of college graduates should be treated as censored data. The relationship between establishment size and main output-destination market shows a very strong pattern: the fraction of establishments with the smallest size is decreasing in market remoteness (e.g., the fraction of smallest firms is 0.85 for the local market while it is 0.29 for the rest of the world). The opposite occurs with the other two size groups. Establishments selling most of their production in non-local markets employ

\footnotetext{
${ }^{8}$ Spanish legislation distinguishes between temporary (or "fixed term") contracts and indefinite (regular) contracts. Temporary contracts were introduced to promote employment. They can be readily terminated once the contract is over and are mainly used to hire young workers in their first employment.
} 


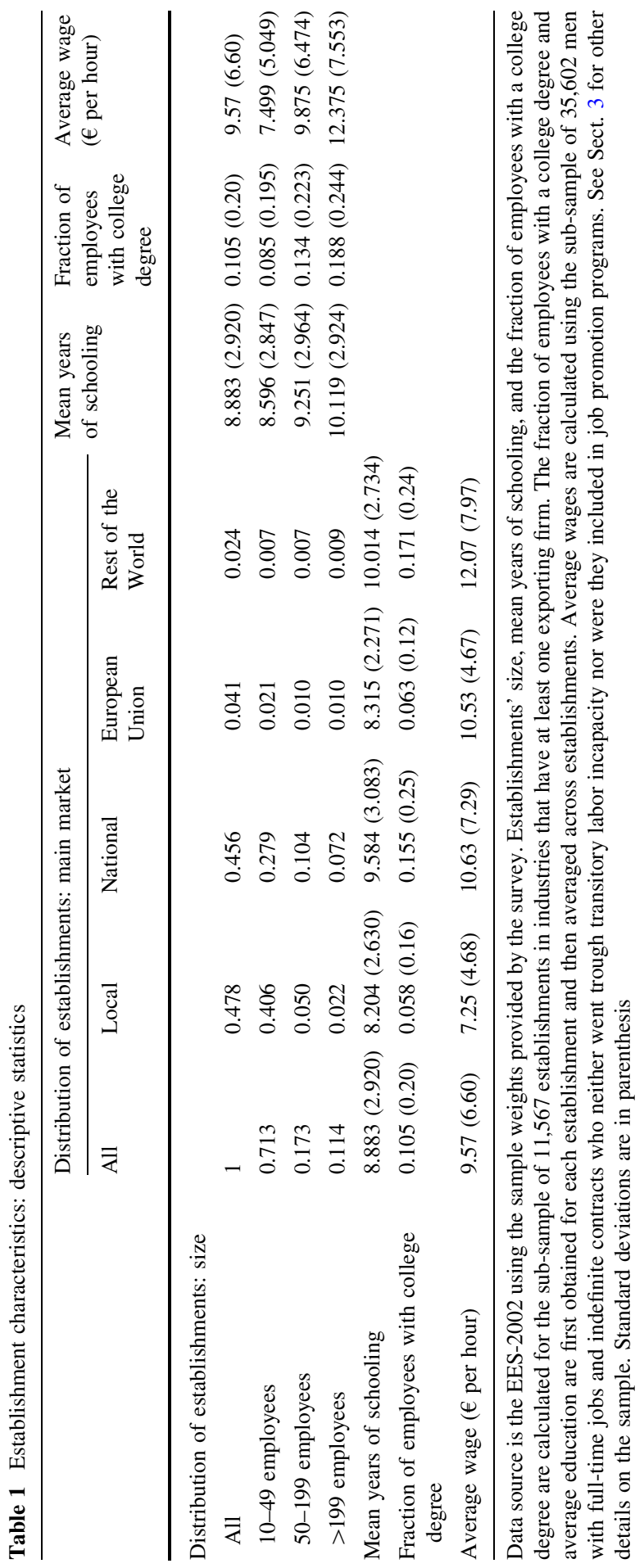


more-educated labor and a larger fraction of workers with a college degree. In particular, the fraction of college graduates in establishments exporting most of their output to countries outside the EU is almost three times higher than in firms selling in local markets.

\section{Establishment characteristics and employees' education}

In this Section, we consider the relationship between main output market and human capital at the establishment level. Previous studies do not use data on firms' average education of employees. They analyze differences between exporters and nonexporters in terms of the composition of occupations and the ratios of blue-collar to white-collar workers (see Bernard and Jensen (1997, 1999), Maurin et al. (2002), Biscourp and Kramarz (2007), and Bernard et al. (2007)). The novelties here are two. We are able to analyze differences in average education across establishments and to go beyond the exporters versus non-exporters distinction by classifying establishments across four main markets: local, national, EU and rest of the world. Our benchmark equation is the following:

$$
e_{j}=\alpha_{0}+\alpha_{1} S 2_{j}+\alpha_{2} S 3_{j}+\alpha_{3} M_{N j}+\alpha_{4} M_{E j}+\alpha_{5} M_{W j}+\alpha_{6} Z_{j}+v_{j} ;
$$

where $e_{j}$ is either employees' average years of schooling in establishment $j$ or, alternatively, the fraction of college-educated employees. The covariates of interest are dummies for size and destination market. $S 2$ corresponds to establishments employing between 50 and 199 workers, and $S 3$ corresponds to establishments with more than 199 workers. $M_{N}, M_{E}$ and $M_{W}$ are dummies for establishments whose main output market is, respectively, the national market, the European Union market, and the rest of the world market. The reference group in estimations using all these covariates is establishments that sell most of their production in a local market and have between 10 and 49 employees. Additionally, we always include a vector $Z j$ of dummies for establishment location (17 regions) and industry (36 industries). $v_{j}$ is the error term. To compare results with previous literature, we also run regressions merging local- and national-market establishments into a single group of domestic-market establishments, and merging EU- and rest of the worldmarket establishments into a single group of exporters.

Table 2 shows the results. Columns (1)-(3) report results using employees' average years of schooling as the left-hand-side variable and estimating the equation by weighted least squares. Column (1) corresponds to the usual specification in the literature, which only distinguishes between exporting firms and domestic-market firms (which is the reference group in this estimation). Still, there is a difference with the previous literature in that we use data on employees' average education instead of the ratio between white and blue-collar workers. Our result confirms the positive and significant effect of exporting on firm's human capital. In column (2) and (3) we use the classification of establishments across all the four main destination markets. The reference group in these two columns is local-market establishments. All destination market dummies in column (2) are positive, significant at the $1 \%$ level, and quantitatively important. National- and European-market destination coefficients are 


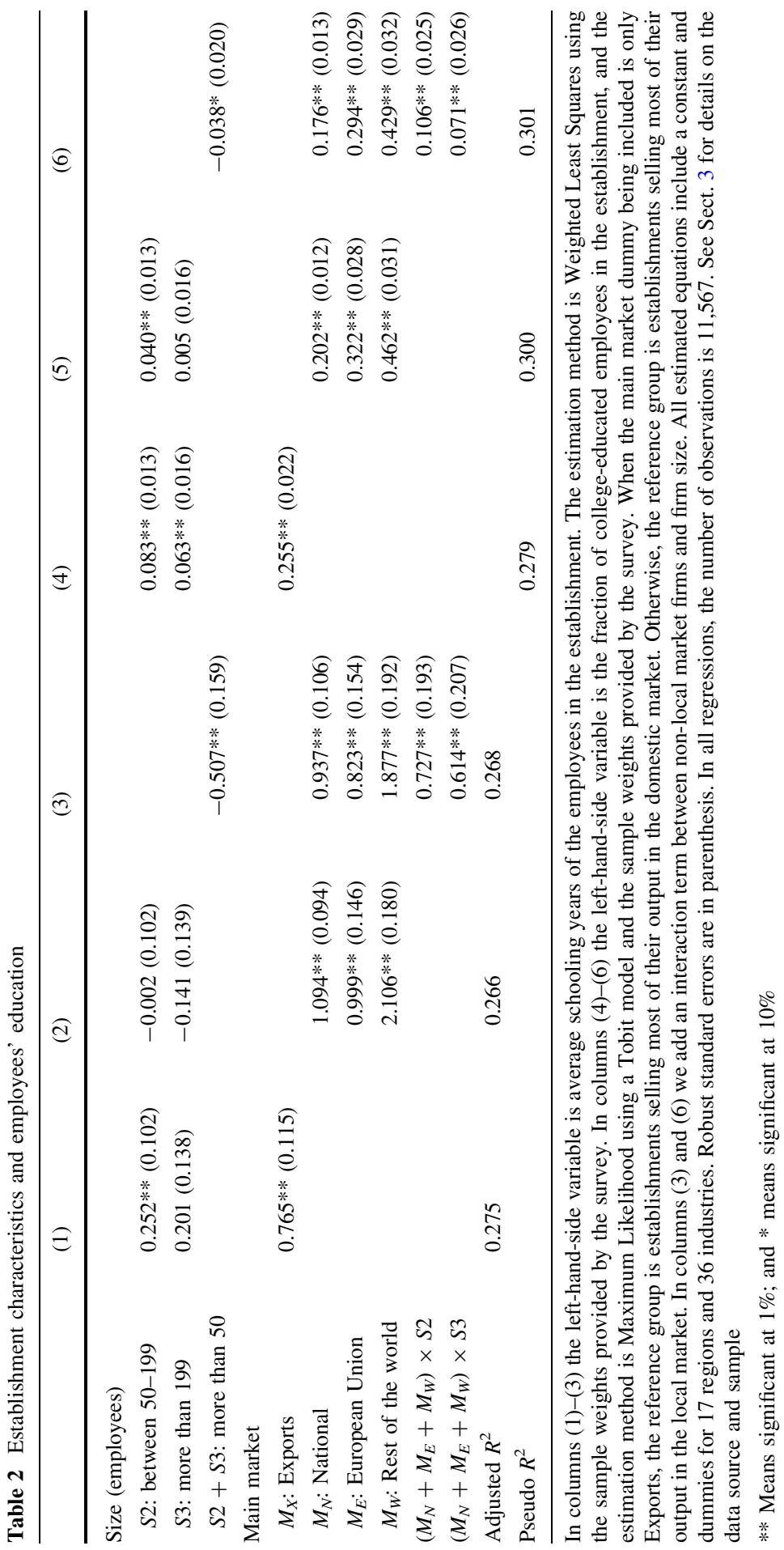


not statistically different. Meanwhile, the difference between local- and nationalmarket firms is as large as the difference between domestic-market firms and exporters found in the previous estimation. ${ }^{9}$

In the case of the size effects, the two dummies become negative though not statistically significant in column (2). This suggests that there may be other reasons - different from higher efficiency — which may also give rise to a large size. In such a case, larger establishment size per se may not imply greater demand for more educated workers unless combined with other characteristics such as non-local destination market. We test this hypothesis in column (3) by introducing an interaction term between size and non-local destination market. The coefficients for large size conditional on selling most of their output in non-local markets are now positive and significant. Large firms employ workers with higher average schooling, only as long as they orient their production to the national or international markets. Conversely, large establishments oriented towards the local markets employ significantly less-educated workers. Coefficients for destination markets in column (3) show the same pattern as in column (2).

In columns (4)-(6) of Table 2 we repeat the same specifications now using the fraction of college graduates in the establishment as the left-hand-side variable. Since about $70 \%$ of establishments in the sample do not include interviews to college-educated workers, least squares estimates may be inconsistent due to censured data problems. We therefore estimate a Tobit model by maximum likelihood. The qualitative results are similar to those reported in columns (1)-(3). All destination market effects are positive and significant. Interestingly, the coefficients are now strictly increasing in the remoteness of the market. Marginal effects implied by the estimated Tobit-model coefficients in column (5) are very large. The proportion of college graduates in national-market firms is $5.6 \%$ points higher than in local-market firms. In EU-market firms, the proportion is $9 \%$ points higher. ${ }^{10}$ Moreover, in firms oriented towards the rest of the world markets, the proportion is $12.9 \%$ points higher than in local-market firms. To asses the importance of these effects, note from Table 1 that the proportion of college graduates in the whole sample is $10.5 \%$.

Summarizing, our empirical results in this section give support to the hypothesis that firms selling to more-distant markets employ more-educated workers. They also show that the conventional dichotomy between exporters and non-exporters may be misleading. In fact, the largest differences across firms do not lie between exporters and non-exporters but between local- and national-

\footnotetext{
9 These results suggest that the organizational changes needed for a local-market firm to expand into the national market may be as important as those needed to expand into foreign markets. Selling in the national market may require a qualitatively different marketing structure and may involve a new logistic ladder between production and retailing, implying new requirements in terms of inventory, warehousing, material handling, packaging, information, and transportation.

10 The absence of a significant difference between national-market firms and exporters to the EU with respect to establishment average years of schooling, while the difference in the share of college graduates is significant and large, is somewhat intriguing. Looking at differences across sectors in future research may provide additional insights on this issue.
} 
market firms, and between exporters to the EU and exporters to the rest of the world.

\section{Establishment characteristics and wages}

We now turn to wages. Our benchmark wage equation is based on the usual Mincerian equation where the log of employee $i$ 's hourly wage in establishment $j$, $w_{i j}$, is a function of his individual characteristics. We include worker's schooling years, $Y_{i j}$; potential experience, $\mathrm{PE}_{i j}$ (level and squared), defined as the difference between employee's age and the expected age to complete his studies according to their official length; and tenure $T_{i j}$ (level and squared), defined as the number of years working for the current employer. To this equation we add establishment $j$ 's characteristics: the two dummies for size already used, employee's average years of schooling, $e_{j}$, the three dummies for main destination market, and a vector $Z_{j}$ of other controls (dummies for 36 three-digit industries and 17 regions). Thus, the benchmark equation is:

$$
\begin{aligned}
\ln w_{i j}= & \beta_{0}+\beta_{1} Y_{i j}+\beta_{2} P E_{i j}+\beta_{3}\left(P E_{i j}\right)^{2}+\beta_{4} T_{i j}+\beta_{5}\left(T_{i j}\right)^{2} \\
& +\beta_{6} S 2_{j}+\beta_{7} S 3_{j}+\beta_{8} e_{j}+\beta_{9} M_{N j}+\beta_{10} M_{E j}+\beta_{11} M_{W j}+\varsigma^{\prime} Z_{j}+u_{i j}
\end{aligned}
$$

where $u_{i j}$ is the residual.

\subsection{Main results}

We estimate several variants of Eq. 1 using weighted least squares and the subsample of men with full-time job and indefinite contracts as described in Sect. 2. Table 3 reports the results. Robust standard errors corrected for the clustered sampling scheme are in parenthesis. All estimations include dummies for 36 threedigit industries and the 17 Spanish regions. Specification in column (1) is different from all the others in this table since it only uses variables at the establishment level. Thus, the left-hand-side variable is (the log of) establishment's average hourly wage (instead of employee's hourly wage, which is the left-hand-side variable in the other columns). As pointed out in the Introduction, this type of regression at the establishment level is the one carried out in most of the literature due to the absence of data at the worker level. The exports market destination in this specification includes all establishments whose main market is either the European Union or the rest of world. The reference group for the effect in this column is establishments whose main output market is the domestic market (i.e., either a local market or the national market). Consistent with most of the literature, we find a positive and significant wage effect of the exports market.

Column (2) reports the results when we use (the log of) employee's hourly wage as the left-hand-side variable and add individual worker characteristics as covariates. The exporting wage premium is reduced but still sizeable and significant at the $1 \%$. This is consistent with the results for Germany in Schank et al. (2007). However, in contrast to their small effects we find that the exporting wage premium 


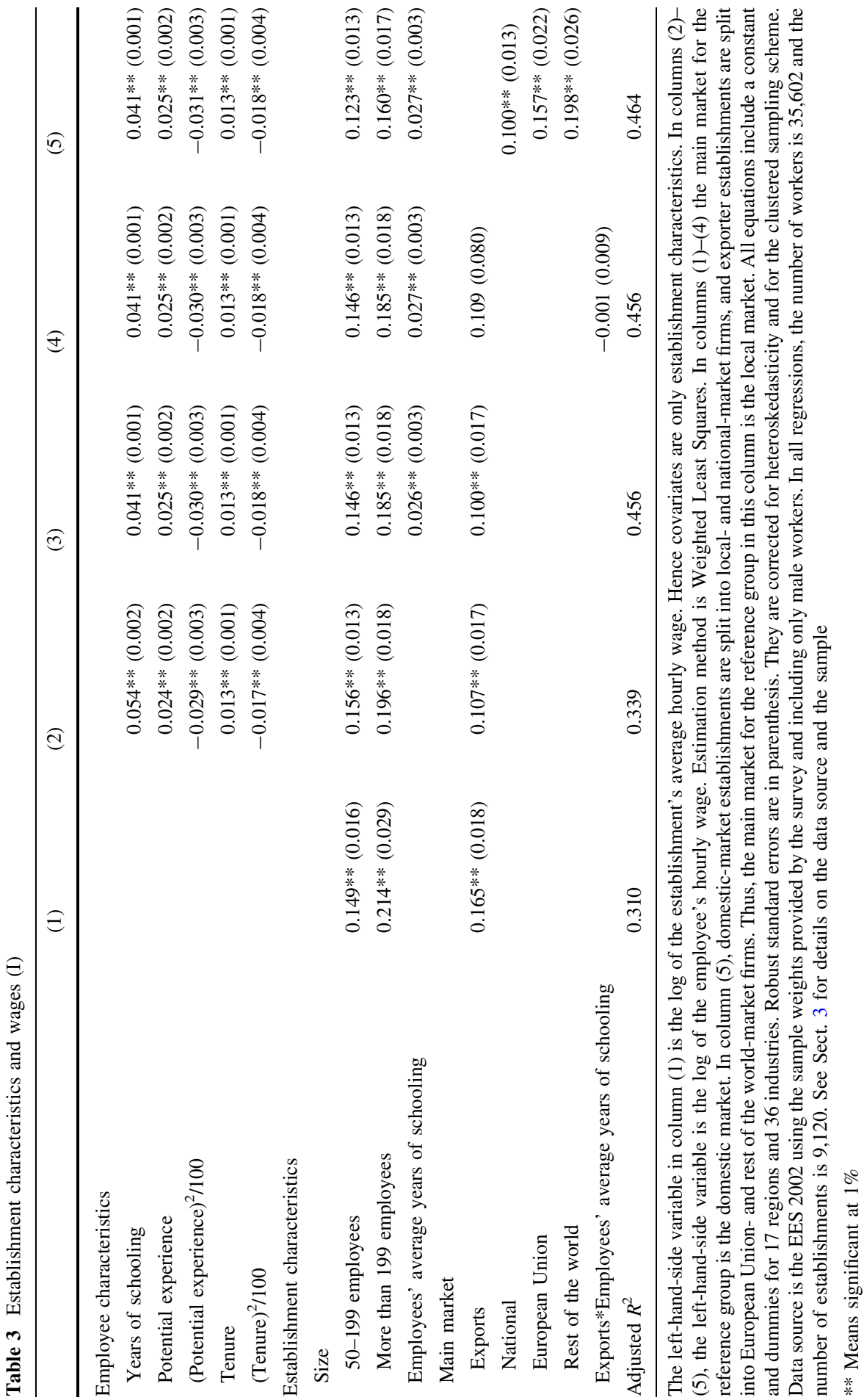


is above 10-percent. This large quantitative discrepancy may be due to the differences in estimation techniques, type of data, ${ }^{11}$ and differences between the German and Spanish economies. ${ }^{12}$

There is an empirical literature pointing at a positive effect of average coworkers' education upon individual wages (see Bayard and Troske (1999), Troske (1999), Battu et al. (2003), and Alcalá and Hernández (2006)). Thus, in column (3) we add employees' average years of schooling to the equation. This effect turns out to be significant and quantitatively important (a 1-year increase in coworkers' schooling increases individual wages by $2.6 \%$ ). Still, the exporter wage premium remains unchanged. Using data for Denmark, Munch and Skaksen (2008) have argued that the export premium is only significant for firms with high skill intensity. They show this by including an interaction term between average education in the firm and export intensity. When they do this, they find the interaction term to be significant whereas the level of export intensity becomes insignificant. To check this hypothesis, we include in column (4) a similar interaction term between the exporter dummy and employees' average years of schooling. We find that the coefficient for the interaction term is almost zero and completely insignificant, whereas the coefficient on the exporter dummy is almost the same as in column (3) (although the coefficient is now estimated with much less precision). Thus, the interaction term has a null explanatory power in our sample.

Column (5) shows the results for our preferred specification. In this specification, we split the groups of non-exporting and exporting establishments. Non-exporting establishments are split into local- and national-market establishments. Exporting firms are split into exporters to the EU and exporters to the rest of the world. When comparing results with those in column (3), note that the reference group is now local-market firms instead of domestic-market firms. All the coefficients have the expected signs, are jointly significant at the $1 \%$ level, and have an important quantitative positive impact on wages. Wages are significantly increasing in the remoteness of the firm's main market. Employees in national-market establishments obtain wages $10.5 \%$ higher than employees with the same observable characteristics in local-market establishments. This wage premium rises to $17.0 \%$ and to $21.9 \%$,

\footnotetext{
11 Schank et al. (2007) use social security payments for information on individual wages. As explained by the authors, these are censored data for one-third of the white-collard workers who, according to previous studies (Bernard and Wagner (1997)) could be the group almost exclusively responsible for the exporting wage premium. In their estimations without individual and plant effects (which would be most similar to ours in column 2) and using imputed data to correct for the censoring problem, they find that an increase in the share of exported output of $10 \%$ points increases the wage of a blue-collar employee (respectively, white-collar) by $0.4 \%$ (resp., $0.12 \%$ ). Note that the average share of exports within total sales in exporting plants reported in the paper is $19 \%$. Since they have a panel of data, they are able to run the regression including individual and plant fixed effects. When they do so, estimates change only slightly though statistical significance increases. They find that an increase in the share of exported output of $10 \%$ points increases the wage of a blue-collar employee (respectively, white-collar) by $0.3 \%$ (resp., $0.15 \%)$.

12 For instance, Spain seems to suffer from bigger problems of relative excess supply of college graduates and over-education [see Dolado et al. (2000)]. This phenomenon could raise wage differences between exporters and non-exporters if the over-education mismatch is higher in non-exporters. This would be the case, for example, if exporters demand a larger share of college graduates and if the fraction of jobs for non-graduates that is occupied by graduates is similar across firms.
} 
respectively, if the main market is the EU and the rest of the world. ${ }^{13}$ Note that the wage premium paid by national-market firms with respect to local-market firms is as important as the premium paid by exporters with respect to national-market firms. This may be somewhat surprising since the export wage premium has given rise to a large literature whereas this is the first paper documenting a national-market wage premium with respect to local firms. Taken together, these estimates suggest a new and important fact: instead of an exporter versus non-exporter dichotomy, there appears to be a continuous positive relationship between wages and the remoteness of firms' output markets, which works even within national borders.

The remaining establishment-characteristic wage premia also have an important quantitative impact. Increasing coworkers' average education by one standard deviation brings about a wage increase of $7.3 \%$; and moving from an establishment in the 10th percentile of the establishment distribution across employees' average education (5 schooling years), to an establishment in the 90th percentile (13.2 schooling years), increases worker's wage by $21.8 \%$. Establishment-size wage premia are also large. The combined effect of all establishment effects can have a very important impact on wage inequality across individuals with the same observable characteristics. For example, according to estimates in column (5), working in a large establishment whose main market is the EU and whose employees' average education is one standard deviation above education in the reference group involves a $47.3 \%$ premium over the wage of a worker with the same individual characteristics but in a small local establishment.

\subsection{Robustness}

Table 4 reports a series of robustness tests. In the specification in column (1) we estimate Eq. 2 using dummies for broad categories of education instead of years of schooling. We use a dummy for workers with completed secondary studies and another dummy for college graduates. As the measure of human capital in the establishment, we use the fraction of employees with a college degree instead of employees' average years of schooling. Results are qualitatively very similar to those in Table 3. All coefficients reveal large quantitative effects, have the expected signs, and are significant at the $1 \%$ level.

In columns (2) and (3) we include additional controls and interactions that help assess the potential impact of alternative sources of the wage premia. Internal labor markets have been suggested as a potential cause of higher average wages in larger firms. Large firms may provide better opportunities for internal promotion and more on-the-job training which then needs to be rewarded to reduce turnover. Hence average wages may be larger for the same level of formal education. Notice that these benefits will not be enjoyed as soon as an individual joins the firm but as the individual continues working for the same firm throughout his life. Therefore, this effect should emerge as a larger payoff to tenure in larger firms. We test this

\footnotetext{
13 We also estimated the impact of firm characteristics on wages using fixed establishment effects and running a two-step estimation of establishment-characteristics coefficients (see Baker and Fortin (2001) for a discussion on the relationship between one-step and two-step estimators). As expected, results were very similar. Results are available on request.
} 
Table 4 Establishment characteristics and wages (II). Robustness using alternative measures for employee and coworkers' education, and including additional controls

Employee characteristics

Years of schooling

High school completed

University degree

Potential experience

(Potential experience $)^{2} / 100$

Tenure

(Tenure) $^{2} / 100$

Establishment characteristics

Size

$$
\text { 50-199 employees }
$$

More than 199 employees

Employees' average years of schooling

Fraction of employees with university degree

Main market

National

European Union

Rest of the world

Firm-level contracting

Tenure $\times$ Size 2

Tenure $\times$ Size 3

Adjusted $R^{2}$
(1)

(2)

(3)

$$
0.041 * *(0.001) \quad 0.041 * *(0.001)
$$

$0.199 * *(0.011)$

$0.466 * *(0.016)$

$0.028 * *(0.002) \quad 0.024 * *(0.002) \quad 0.024 * *(0.002)$

$-0.038 * *(0.003)-0.030 * *(0.003)-0.030 * *(0.003)$

$0.014 *(0.001) \quad 0.013 * *(0.001) \quad 0.013 * *(0.001)$

$-0.021 * *(0.004)-0.021 * *(0.004) \quad-0.020 * *(0.004)$

$$
\begin{array}{lll}
0.130 * *(0.013) & 0.128 * *(0.017) & 0.124 * *(0.017) \\
0.175 * *(0.017) & 0.128 * *(0.023) & 0.109 * *(0.023) \\
& 0.023 * *(0.003) & 0.023 * *(0.003)
\end{array}
$$

$$
\begin{array}{lll}
0.091 * *(0.013) & 0.099 * *(0.013) & 0.100 * *(0.013) \\
0.143 * *(0.021) & 0.155 * *(0.022) & 0.158 * *(0.022) \\
0.170 * *(0.024) & 0.199 * *(0.026) & 0.207 * *(0.026) \\
& & 0.074 * *(0.022) \\
& -0.0003(0.001) & -0.0006(0.001) \\
& 0.0025 * *(0.001) & 0.002(0.001) \\
0.485 & 0.464 & 0.478
\end{array}
$$

The left-hand-side variable is the log of the hourly wage. All models include a constant and dummies for 17 regions and 36 industries. The reference group for establishment effects is establishments with less than 50 employees selling mostly to a local market. Estimation method is Weighted Least Squares. Robust standard errors corrected for heteroskedasticity and for the clustered sampling scheme in parenthesis. The model in column (1) is the same as in column (5) of Table 3, except that we now use dummies for broad categories of education instead of years of schooling to control for employee's education; and that we use the fraction of employees with a college degree instead of coworkers' average years of schooling. In all regressions, the number of workers is 35,602 and the number of establishments is 9,120 . See Sect. 3 for details on the data

** Means significant at $1 \%$

hypothesis in column (2) by including interaction terms between tenure and the dummies for firm size. The interaction with the largest size turns out to be positive and statistically significant. Tenure in the largest group of establishments is about $25 \%$ more profitable than in small establishments.

It has also been suggested that workers and unions in large firms often have a strong bargaining power that is reflected in higher wages. The common mechanism used by workers and unions to exert their bargaining power in Spain is through firmlevel contracting. In column (3), we add a dummy for establishments with firm-level contracting. This effect is highly significant and involves an average wage increase 
of $7.4 \% .{ }^{14}$ However, it does not affect the significance of any of the variables in our original model and, if any, it has a positive effect on the estimated value of the coefficients on output markets.

\subsection{Establishment-characteristics effects by education groups}

Are establishment-characteristics wage effects significant for all education groups? Do their quantitative effects show any pattern across education groups? We investigate this issue by estimating Eq. 2 for each of the three major education categories: workers without completed secondary education, with completed secondary education, and with a college degree. We include the firm-level contracting dummy and the size-tenure interaction term in the estimating equation since we just checked their potential significance. Table 5 shows the results. Coefficients for all establishment characteristics are significant at the $1 \%$ level in all sub-samples and have the expected positive signs (except firm-level contracting and the size-tenure interaction terms, which are not always significant). Differences across education groups in the size of the establishment-characteristic wage effects are sizable and follow a systematic, intuitively appealing pattern. All effects are increasing in the level of education, whenever the difference across education groups is statistically significant. ${ }^{15}$

Results are especially sharp for main-market effects. Coefficients are increasing in the remoteness of the main destination market for each education group, whenever the difference between coefficients is statistically significant. Note that the effects for the university education group about triple those for the primary education group. When combined with the other establishment wage effects, they can account for dramatic wage differences across workers with the same observable characteristics, especially within college graduates. As an example, consider the establishment wage premium for a college graduate working in a medium-size firm that exports most of its production to the EU and whose employees' average education is one standard deviation above the mean. On average, this individual obtains a wage that is $110.4 \%$ higher than an individual with the same education and experience who works in a small local-market firm whose employees' average education is one standard deviation below the mean. The substantial size of

\footnotetext{
14 In their specific analysis on firm-level contracting, Card and De la Rica (2006) point out that firm-level contracting is more likely to occur where there is (or there was) a strong union presence. Our estimate of this effect is very consistent with their results.

15 These results stand in contrast with those in the small literature on this issue. Battu et al. (2003) analyze the establishment average-education wage premium in the UK and find that it is decreasing in the individual's education, albeit they recognize that this runs counter to their theoretical prediction. Lallemand et al. (2005) analyze the firm-size wage premium and find that it is generally larger for bluecollar workers. To the extent that the blue-collard versus white-collard comparison can be related to our education-groups comparison, our results would point in the opposite direction. However, they do not control for firm-level contracting, nor for the interaction between tenure and size. These two effects are highly significant for the least educated workers and seem responsible for a large fraction of the wage premium that less-educated workers obtain in large firms. Additional results not included in the Table 5 show that if we did not control for firm-level contracting and the tenure-size interaction, the largest firmsize premium would be attributed to the lowest education group.
} 
Table 5 Establishment characteristics and wages by education group

\begin{tabular}{llll}
\hline & Primary & Secondary & University \\
\hline Employee characteristics & & & \\
$\quad$ Potential experience & $0.016^{* *}(0.001)$ & $0.027^{* *}(0.003)$ & $0.061^{* *}(0.005)$ \\
$\quad$ Potential experience $)^{2} / 100$ & $-0.020^{* *}(0.003)$ & $-0.031^{* *}(0.007)$ & $-0.001^{* *}(0.013)$ \\
Tenure & $0.014^{* *}(0.015)$ & $0.017^{* *}(0.003)$ & $0.014^{* *}(0.006)$ \\
(Tenure) $)^{2} / 100$ & $-0.023^{* *}(0.005)$ & $-0.027^{* *}(0.008)$ & $-0.034^{* *}(0.014)$ \\
Establishment characteristics & & & \\
Size & & & \\
50-199 employees & & & \\
$\quad$ More than 199 employees & $0.113^{* *}(0.017)$ & $0.157^{* *}(0.028)$ & $0.178^{* *}(0.048)$ \\
Employees' average years of schooling & $0.016^{* *}(0.0026)$ & $0.169^{* *}(0.035)$ & $0.147 * *(0.048)$ \\
Main market & & $0.028^{* *}(0.004)$ & $0.044^{* *}(0.009)$ \\
$\quad$ National & $0.050^{* *}(0.013)$ & $0.136^{* *}(0.022)$ & $0.145^{* *}(0.037)$ \\
$\quad$ European Union & $0.094^{* *}(0.022)$ & $0.201^{* *}(0.038)$ & $0.309^{* *}(0.076)$ \\
$\quad$ Rest of the world & $0.116^{* *}(0.022)$ & $0.238^{* *}(0.038)$ & $0.291^{* *}(0.065)$ \\
Firm-level contracting & $0.100^{* *}(0.024)$ & $0.056^{*}(0.028)$ & $0.069(0.039)$ \\
Tenure $\times$ Size 2 & $0.002^{*}(0.001)$ & $-0.004^{*}(0.002)$ & $-0.009 * *(0.004)$ \\
Tenure $\times$ Size 3 & $0.005^{* *}(0.001)$ & $-0.002(0.002)$ & $-0.006(0.005)$ \\
Number of establishments & 7,466 & 3,966 & 1,856 \\
Number of workers & 21,705 & 9,594 & 4,303 \\
Adjusted $R^{2}$ & 0.404 & 0.394 & 0.327 \\
\hline We & &
\end{tabular}

We use three different sub-samples of workers according to their education level: workers without completed secondary studies (Primary), workers with completed secondary studies (Secondary), and workers with a college degree (University). The left-hand-side variable is the log of the hourly wage. The reference group for establishment effects is establishments with less than 50 employees selling mostly to a local market. Estimation method is Weighted Least Squares. All models include a constant and dummies for 17 regions and 36 industries. Robust standard errors corrected for heteroskedasticity and for the clustered sampling scheme are in parenthesis. See Sect. 3 for details on the data source and sample ** Means significant at $1 \%$, and * means significant at $10 \%$

destination-market wage effects and their large differences across education groups suggest that expanding globalization may play an important role in increasing inequality within and between education groups.

\section{Firms' human capital, wages, and output markets: a model}

In this section, we lay out a partial equilibrium model where firms choose which output quality and quantity to produce, which combination of workers with different characteristics to employ, and which destination markets to serve. The aim is to build a model that: (1) can provide a joint explanation for all the firm-characteristics effects on human capital and wages; and (2) is consistent with the related empirical evidence documented in the recent trade literature. As noted in the Introduction, this literature shows that international trade models need to introduce efficiency 
heterogeneity at the firm level and quality differentiation in order to be consistent with several prominent, current patterns of international trade.

\subsection{Technology and demand}

Firm $j$ produces output $y_{j}$ with quality $q_{j}$ using physical capital and different types of labor. The different types of labor are characterized by two attributes: education and skill. Firms can observe both attributes. However, skill is meant to represent worker unmeasured characteristics which cannot be controlled for in the econometric analysis. Workers can be educated $(E)$ or non-educated $(N)$, and skilled $(S)$ or unskilled $(U)$. Hence, there are four types of workers. Let $k_{j}$ be firm $j$ 's capital and $l_{j}^{i s}$ the number of type is workers it employs; $i=N, E ; s=U, S$. Producing higher quality comes at the cost of lower output per worker, according to the following production function:

$$
y_{j}=A_{j}\left(\frac{a_{k}}{\left(q_{j}\right)^{\gamma_{k}}}\left(k_{j}\right)^{\rho}+\sum_{s=U, S} \sum_{i=N, E} \frac{a_{i s}}{\left(q_{j}\right)^{\gamma_{i s}}}\left(l_{j}^{i s}\right)^{\rho}\right)^{1 / \rho} ; \quad \gamma_{k}, \gamma_{i s} \geq 1 ; \rho<1 ;
$$

where $A_{j}$ is a firm-specific efficiency parameter (all other parameters are common to all firms). Note that, for any given choice of output quality $q_{j}$, this is a standard CES production function. Moreover, technical marginal rates of substitution between different types of labor depend on the quality to be produced:

$$
\frac{\mathrm{d} l_{j}^{i s}}{\mathrm{~d} l_{j}^{i^{\prime} s^{\prime}}}=\left(q_{j}\right)^{\gamma_{i s}-\gamma_{i^{\prime} s^{\prime}}} \frac{a_{i^{\prime} s^{\prime}}}{a_{i s}}\left(\frac{l_{j}^{i s}}{l_{j}^{i^{\prime} s^{\prime}}}\right)^{1-\rho} .
$$

Thus, if $\gamma_{i s}<\gamma_{i^{\prime} s^{\prime}}$ then $\mathrm{d} l_{j}^{i s} / \mathrm{d} l_{j}^{l^{\prime} s^{\prime}}$ decreases as quality increases. We assume:

$$
\gamma_{E S}<\gamma_{N S}<\gamma_{N U} ; \quad \gamma_{E S}<\gamma_{E U}<\gamma_{N U}
$$

Hence unskilled (resp., non-educated) labor becomes a worse substitute for skilled (resp., educated) labor as quality increases. Or, in other words, skilled (respectively, educated) labor has a comparative advantage with respect to unskilled (resp., noneducated) labor in producing higher quality. ${ }^{16}$

\footnotetext{
16 In general, less-skilled labor may perform the work of more-skilled labor by devoting more time to the task. However, producing high quality output tends to become increasingly difficult for low-skilled labor. In the limit, it may be impossible for low skilled labor to produce the highest quality, even if devoting an unlimited amount of time. For example, it is unlikely that the service provided in a top restaurant by highskilled waiters can be provided by low-skilled waiters even if their number is larger. Similarly, it is doubtful that a low-skilled architect may be able to design innovative solutions to outstanding architectural problems by simply devoting more time to the project. Quite often, quality requires not only time but talent. This suggests that unskilled workers' marginal productivity decreases fast as the quality being targeted increases and may even go to zero for very high qualities. With this perspective, it is often assumed in models with quality differentiation and heterogeneous labor that goods of higher quality can only be produced by workers with certain minimum human capital (see, for example, Stokey 1991 and Verhoogen 2008). In this model we introduce the weaker and more flexible assumption that the technical marginal rate of substitution between skilled (resp. educated) labor and unskilled (resp. non-educated) labor is decreasing in the quality to be produced.
} 
On the demand side, we assume identical consumers across markets, though markets may differ in size (i.e., the number of consumers). Superscript $n$ indicates the market. Demand for firm $j$ 's output in market $n, y_{j}^{n}$, is homogeneous of degree one in market $n$ 's size, $M^{n}$, decreasing in the firm's price, $p_{j}^{n}$, and increasing in the firm's output quality, $q_{j}^{n}$, according to the following inverse demand function:

$$
p_{j}^{n}=\theta\left(q_{j}^{n}\right)+\sigma\left(y_{j}^{n} / M^{n}\right) .
$$

Thus, quality is just a shifter of the demand function. ${ }^{17}$ It is assumed ${ }^{18}$

$$
\begin{aligned}
& \frac{\partial \theta}{\partial q_{j}^{n}} \equiv \theta^{\prime}>0, \quad \frac{\partial^{2} \theta}{\partial\left(q_{j}^{n}\right)^{2}} \equiv \theta^{\prime \prime} \leq 0, \\
& \frac{\partial \sigma}{\partial\left(y_{j}^{n} / M^{n}\right)} \equiv \sigma^{\prime}<0 ; \quad-\left(y_{j}^{n} / M^{n}\right) \frac{\sigma^{\prime \prime}}{\sigma^{\prime}}<2 ; \\
& \theta(1)+\sigma(0)=0 .
\end{aligned}
$$

The last expression is just a normalization on quality. Quality is normalized such that $q=1$ is the minimum quality for the good to be of any use (thus, demand is strictly positive at a zero price if and only if $q>1$ ).

\subsection{Production and transportation costs}

Labor markets are perfectly competitive. Since education and skills are observable to all agents, workers with the same characteristics earn the same wage no matter their employers. Denote the cost of capital by $r$ and wages by $w^{i s}$, which are exogenous to the firm. ${ }^{19}$ It is natural to assume $w^{E S}>w^{E U}$ and $w^{N S}>w^{N U}$.

\footnotetext{
${ }^{17}$ It has been shown that this indirect demand function can be obtained as a result of utility maximization in a market with a continuum of consumers of measure $M^{n}$ and the following assumptions. Each individual consumes a variable amount of a non-differentiated good (which is used as the numeraire) and one unit of a differentiated good. The differentiated good is produced by a measure, $J$ continuum of firms which are indexed by $j$. Utility if consuming the variety produced by firm $j$ is $U_{j}=u(z)+q_{j}+\varepsilon$, where $u(\cdot)$ is the subutility function for the non-differentiated good satisfying standard conditions, $z$ is consumption of this good, and $\varepsilon$ is a random consumer/differentiated-good match term. Assuming that the price of each variety of the differentiated good is small with respect to consumers' income and under standard conditions for the random term $\varepsilon$, this utility implies the following inverse market demand function: $p_{j}^{n}=\bar{\theta} \cdot q_{j}^{n}-\bar{\sigma} \cdot \ln \left(y_{j}^{n} / M^{n}\right)-\bar{\sigma} \cdot \ln \int_{J} \exp \left[(\bar{\theta} / \bar{\sigma}) q_{j}^{n}-(1 / \bar{\sigma}) p_{j}^{n}\right] d j$, where $\bar{\theta}$ and $\bar{\sigma}$ are positive parameters that may depend on consumers' income. See Verhoogen 2008 for details on this derivation and for further references. Assuming that the number of firms is large, each firm takes the last term in this expression as a constant to maximize profits. Equation 4 is then a slight generalization of this expression, where the linear function on $q_{j}^{n}$ and the logarithmic function on $\left(y_{j}^{n} / M^{n}\right)$ are substituted for the more general functions $\theta(\cdot)$ and $\sigma(\cdot)$.

18 The condition $-\left(y_{j}^{n} / M^{n}\right) \sigma^{\prime \prime} / \sigma^{\prime}<2$ on the curvature of the (per capita) inverse demand function $\sigma$ guarantees the second order conditions for profit maximization.

19 Assuming that firms have different access to financial markets (e.g., they face different cost of capital $r$ ) would have implications similar to the existence of differences in the efficiency parameter $A_{j}$.
} 
Minimization of the cost function $C_{j}(y, q)=r k_{j}+\sum_{s} \sum_{i} l_{j}^{i s} w^{i s}$ for a given pair $\left(y_{j}, q_{j}\right)$ subject to the production function yields the following first order conditions:

$$
\frac{a_{k}}{\left(q_{j}\right)^{\gamma_{k} r}}\left(k_{j}\right)^{\rho-1}=\frac{a_{i s}}{\left(q_{j}\right)^{\gamma_{i s}} w^{i s}}\left(l_{j}^{i s}\right)^{\rho-1} ; \quad i=N, E ; \quad s=U, S .
$$

Hence the cost function for optimal input decisions is:

$$
C_{j}\left(y_{j}, q_{j}\right)=\frac{\phi\left(q_{j}\right)}{A_{j}} y_{j} ; \quad \text { where } \phi\left(q_{j}\right) \equiv\left(\left(\frac{\left(q_{j}\right)^{\gamma_{k}}}{a_{k}} r\right)^{\frac{\rho}{\rho-1}}+\sum_{s} \sum_{i}\left(\frac{\left(q_{j}\right)^{\gamma_{i s}}}{a_{i s}} w^{i s}\right)^{\frac{\rho}{\rho-1}}\right)^{\frac{\rho-1}{\rho}} .
$$

Note that $\phi^{\prime}\left(q_{j}\right)>0$ and $\phi^{\prime \prime}\left(q_{j}\right)>0$. Hence, unit costs $\phi\left(q_{j}\right)>A_{j}$ are constant with respect to quantity, and increasing and convex with respect to quality.

So far, we have only considered production costs. Selling to each market involves specific transportation and other non-production costs. We assume that selling to market $n$ involves an additional cost $\tau^{n}$ per unit of output. We may expect this cost to be increasing in the remoteness of the market. Thus, firm $j$ 's constant marginal cost of producing and selling quality $q_{j}$ in market $n$, denoted $c_{j}^{n}\left(q_{j}\right)$, is:

$$
c_{j}^{n}\left(q_{j}\right)=\frac{\phi\left(q_{j}\right)}{A_{j}}+\tau^{n} ; \quad \phi^{\prime}>0, \phi^{\prime \prime}>0
$$

\subsection{Equilibrium and output markets}

For each market $n$, firm $j$ 's profit maximization yields the following first order conditions that determine the optimal volume of sales $y_{j}^{n^{*}}$ and quality $q_{j}^{n^{*}}$ in market $n$ :

$$
\begin{gathered}
\theta^{\prime}\left(q_{j}^{n^{*}}\right)=\frac{\phi^{\prime}\left(q_{j}^{n^{*}}\right)}{A_{j}} ; \\
y_{j}^{n^{*}} / M^{n}=\frac{\theta\left(q_{j}^{*}\right)+\sigma\left(y_{j}^{n^{*}} / M^{n}\right)-\phi\left(q_{j}^{*}\right) / A_{j}-\tau^{n}}{-\sigma^{\prime}\left(y_{j}^{n^{*}} / M^{n}\right)} .
\end{gathered}
$$

Assuming $\theta^{\prime}(1)>\phi^{\prime}(1) / A_{j}$, Eq. 8 has a unique solution $q_{j}^{*}>1$, which is independent of the market. Since $\theta^{\prime \prime}(q) \leq 0$ and $\phi^{\prime \prime}(q)>0$, Eq. 8 implies that higher-efficiency firms choose higher quality in equilibrium:

$$
\frac{\mathrm{d} q_{j}^{*}}{\mathrm{~d} A_{j}}=\frac{\theta^{\prime}}{\phi^{\prime \prime}-A_{j} \theta^{\prime \prime}}>0 .
$$

In turn, sales by more-efficient firms are larger in every market where they are active: ${ }^{20}$

\footnotetext{
${ }^{20}$ Note that assumptions on $\sigma(\cdot)$ imply that $2+\left(y_{j}^{n} / M^{n}\right) \sigma^{\prime \prime} / \sigma^{\prime}$ is positive.
} 


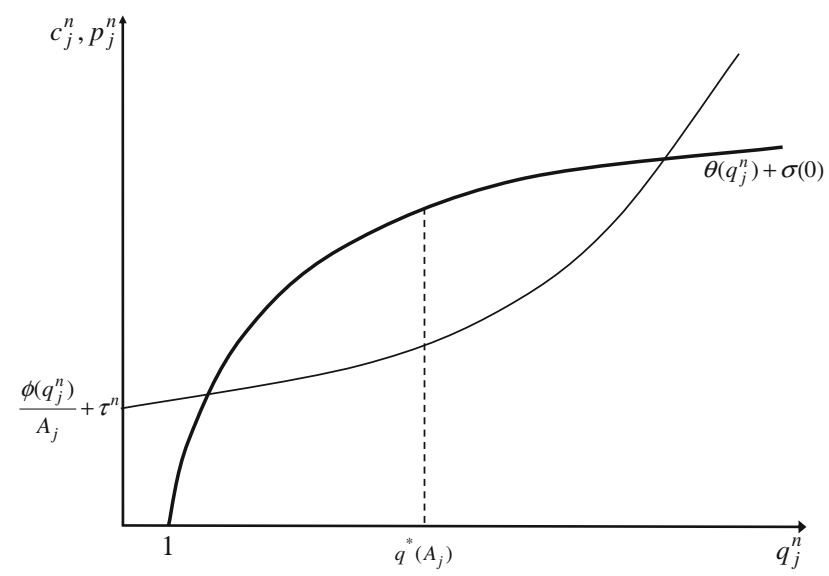

Fig. 1 Unit costs and maximum prices for each quality

$$
\frac{\mathrm{d} y_{j}^{n^{*}}}{\mathrm{~d} A_{j}}=-\frac{M^{n}}{\sigma^{\prime}} \frac{\phi}{\left(A_{j}\right)^{2}} \frac{1}{2+\left(y_{j}^{n^{*}} / M^{n}\right) \sigma^{\prime \prime} / \sigma^{\prime}}>0 .
$$

Clearly, expression (9) only holds conditional on the firm being active in market $n$; that is, conditional on $y_{j}^{n^{*}}>0$. Let us analyze the decision to be active in a given market. A firm will be active in a given market as long as, for an optimal quality choice, the firm can sell a positive output at a price higher than the corresponding constant marginal cost (unit cost). Consider Fig. 1. The thicker line draws the inverse demand function (4) for $y_{j}^{n}=0$. This line shows the maximum prices that firm $j$ could obtain for each quality level. For $y_{j}^{n}>0$, the price schedule would shift downwards. The thinner line in this figure draws firm's unit cost as a function of output quality. If there is a non-empty set of possible qualities such that firm unit cost is below the corresponding price (as in Fig. 1), then the firm can profitably sell in market $n$. In fact, any quality-price pair in the space contained between these two schedules would bring about positive profits. ${ }^{21}$ For lower efficiency $A_{j}$, the cost schedule would shift upwards.

Given the cost $\tau^{n}$ of exporting to market $n$, there is an efficiency level sufficiently low, denoted $\bar{A}^{n}$, such that the two schedules are tangent (see Fig. 2). This efficiency level satisfies:

$$
\theta\left(q_{j}^{*}\left(\bar{A}^{n}\right)\right)-\sigma(0)=\frac{\phi\left(q_{j}^{*}\left(\bar{A}^{n}\right)\right)}{\bar{A}^{n}}+\tau^{n} .
$$

Clearly, $\bar{A}^{n}$ is the efficiency cutoff for a firm to be active in market $n$. Firms such that $A_{j}<\bar{A}^{n}$ cannot make non-zero profits at any positive output and quality levels.

\footnotetext{
${ }^{21}$ Optimal quality corresponds to the level such that the two schedules have the same slope (see expression 8). The optimal price (and therefore, the optimal volume of sales) could be shown in the figure by drawing the iso-profit ellipses within the space contained between the two schedules.
} 


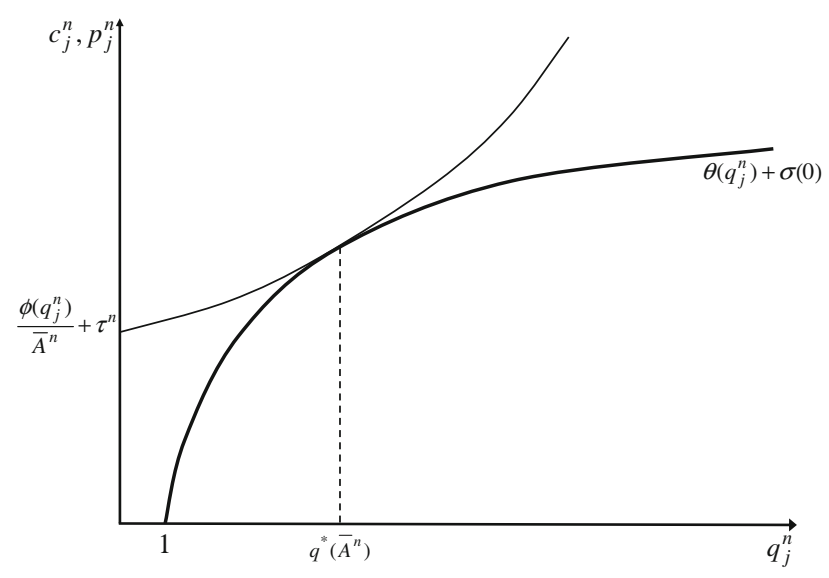

Fig. 2 Efficiency cutoff to be active in market $n$

The efficiency cutoff $\bar{A}^{n}$ for market $n$ is increasing in the cost of bringing the product to this market:

$$
\frac{\partial \bar{A}^{n}}{\partial \tau^{n}}=\frac{\left(\bar{A}^{n}\right)^{2}}{\phi\left(q_{j}^{*}\left(\bar{A}^{n}\right)\right)}>0 .
$$

This implies that the number and remoteness of markets in which a firm sells is informative about its efficiency: if firm $j$ sells in market $n$ but firm $j$ ' does not, it must be the case that $A_{j}>\bar{A}^{n} \geq A_{j^{\prime}}$. Since more-efficient firms produce higher quality, this implies that firms selling in more and more-remote markets produce higher quality. In addition, more-efficient firms are also larger in terms of output because their sales are bigger in every market where they are active [expression (9)] and because they are active in more markets.

It is worth pointing out the main difference between this model and previous models on the link between a firm's efficiency and the number and remoteness of its destination markets, which follow Melitz (2003). Previous models assume that each firm faces a strictly positive demand for its output, in every market, at any positive price set by the firm. This is, for example, the consequence of assuming CES preferences, which is the usual assumption in the literature. Therefore, in the absence of fixed costs of exporting to each destination, these models would imply that all firms export to all markets. Hence, fixed cost of exporting to each market (together with the fact that more-efficient firms are larger) is the key mechanism in these models for the result that only the more efficient firms sell in the more remote markets. To the contrary, in this model, each individual firm faces a demand with finite choke prices for each quality. Consequently, the reason why the less-efficient firms do not sell in the more-remote markets is their inability to produce at low enough marginal costs. Furthermore, the mechanism for the link between destination-market remoteness and export quality (the Alchian-Allen effect) in this model is also different from the usual one. The mechanism usually considered is that if transport costs are not proportional to shipment's value but have a per unit 
component, a higher transport cost to a more remote market reduces the relative price of higher-quality exports with respect to lower-quality exports (see Hummels and Skiba 2004). Then, under usual assumptions on demand, this implies that shipments to more remote markets have a bigger proportion of higher-quality goods. The mechanism in this model is that the higher the trade costs, the stronger the selection effect on exporters. Since more-efficient firms produce higher quality, trade costs result in higher-quality exports to more remote markets. In the next subsection, we turn to the model's implications on human capital and wage differences across firms.

\subsection{Labor sorting and average wages}

Consider now the education and skill composition of employees in firm $j$. We assume an interior solution; i.e., $l_{j}^{i s}>0$. From expression (5) we have that, for each education group, the ratio of skilled workers is larger in firms producing higher quality:

$$
\frac{\mathrm{d}\left(l_{j}^{i S} / l_{j}^{i U}\right)}{\mathrm{d} q_{j}}=\frac{\gamma_{i U}-\gamma_{i S}}{1-\rho}\left[\frac{a_{i S} w^{i U}}{a_{i U} w^{i S}} q_{j}^{\gamma_{i U}-\gamma_{i S}}\right]^{1 /(1-\rho)} q_{j}^{-1}>0, \quad i=N, E .
$$

Similarly, for each skill group, the ratio of educated workers is larger in firms producing higher quality:

$$
\frac{\mathrm{d}\left(l_{j}^{E s} / l_{j}^{N s}\right)}{\mathrm{d} q_{j}}=\frac{\gamma_{N s}-\gamma_{E s}}{1-\rho}\left[\frac{a_{E s} w^{N s}}{a_{N s} w^{E s}} q_{j}^{\gamma_{N s}-\gamma_{E s}}\right]^{1 /(1-\rho)} q_{j}^{-1}>0, \quad s=U, S .
$$

Denote $l_{j}^{E} \equiv l_{j}^{E U}+l_{j}^{E S}, l_{j}^{N} \equiv l_{j}^{N U}+l_{j}^{N S}, l_{j} \equiv l_{j}^{E}+l_{j}^{N}$. Assuming $l_{j}^{E S} / l_{j}^{E} \geq l_{j}^{N S}$ / $l_{j}^{N},{ }^{22}$ the last expression yields that the ratio of educated workers $e_{j}=l_{j}^{E} / l_{j}$ is also larger in firms producing higher quality:

$$
\frac{\mathrm{d} e_{j}}{\mathrm{~d} q_{j}}=\frac{l_{j}^{N} l_{j}^{E}}{\left(l_{l}\right)^{2}}\left[\frac{1}{l_{j}^{E}} \frac{\mathrm{d} l_{j}^{E}}{\mathrm{~d} q_{j}}-\frac{1}{l_{j}^{N}} \frac{\mathrm{d} l_{j}^{N}}{\mathrm{~d} q_{j}}\right]>\frac{l_{j}^{N} l_{j}^{E}}{\left(l_{l}\right)^{2}}\left(\frac{l_{j}^{E S}}{l_{j}^{E}}-\frac{l_{j}^{N S}}{l_{j}^{N}}\right)\left[\frac{1}{l_{j}^{N S}} \frac{\mathrm{d} l_{j}^{N S}}{\mathrm{~d} q_{j}}-\frac{1}{l_{j}^{N U}} \frac{\mathrm{d} l_{j}^{N U}}{\mathrm{~d} q_{j}}\right] \geq 0 .
$$

Now, since more-efficient firms produce higher quality, Eqs. 11 and 12 imply that more-efficient firms use a larger proportion of skilled workers within each education group and a larger proportion of high-education workers with respect to their total employment:

$$
\begin{gathered}
\mathrm{d}\left(l_{j}^{i S} / l_{j}^{i U}\right) / \mathrm{d} A_{j}>0 ; \quad i=N, E \\
\mathrm{~d} e_{j} / \mathrm{d} A_{j}>0 .
\end{gathered}
$$

Let $w_{j}^{i}$ denote the average wage paid by firm $j$ to workers with education level $i$ :

\footnotetext{
$\overline{22}$ It is seems unanimously agreed that unmeasured skills and education are positively correlated. Hence the fraction of skilled workers that are educated should be larger than the fraction of unskilled that are educated.
} 


$$
w_{j}^{i}=\frac{w^{i U} l_{j}^{i U}+w^{i S} l_{j}^{i S}}{l_{j}^{i U}+l_{j}^{i S}}=w^{i U} \frac{1+\left(w^{i S} / w^{i U}\right) l_{j}^{i S} / l_{j}^{i U}}{1+l_{j}^{i S} / l_{j}^{i U}}, \quad i=N, E .
$$

Since $w^{i S} / w^{i U}>1, i=E, N$, expression (13) implies that more efficient firms pay higher average wages to employees in every education level:

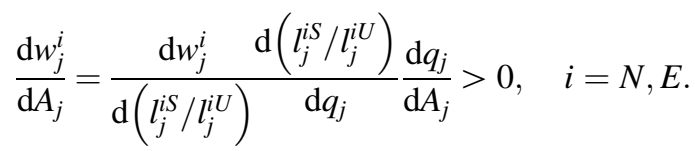

Note that the positive relationship between efficiency and average wages is the consequence of the (equilibrium) positive relationship between efficiency and quality. If output quality were assumed the same for all firms as in conventional models, firms would choose the same labor composition no matter their efficiency. ${ }^{23}$

In summary, the model shows that, under reasonable assumptions, quality differentiation implies that more-efficient firms employ more-skilled and moreeducated workers. Since, in equilibrium, more-efficient firms also sell in moredistant markets, we should observe that: (1) Firms selling in more-remote countries employ workers with higher average education; (2) Firms selling in more-remote countries pay higher average wages to workers within each education group. Additionally, since more-efficient firms also have larger size, we should also observe a positive link (a) between firm's size and employees' average education; (b) between firm's size and average wages paid to each education group; and (c) between employees' average education and average wages paid to each education group. Thus, the model provides a consistent explanation of all the empirical regularities found in Sects. 3 and 4. Moreover, the model is consistent with the recent trade literature stressing the increasing role in international trade played by quality differentiation and the positive relationship between output-market remoteness and the quality of exports.

\section{Concluding comments}

This paper contributes to the recent literature on the exporter wage premium using Spanish data. This literature has focused on an exporter/non-exporter dichotomy. Instead, this paper provides first evidence that that there is a more continuous destination-market effect. We find a positive correlation between remoteness of firms' output-markets and their human capital as well as their wages. In fact, wage premia and human capital differences between local- and national-market firms are as important as wage premia and human capital differences between exporters and non-exporters. Overall, market-remoteness wage premia are quantitatively very

\footnotetext{
${ }^{23}$ There is also some empirical evidence on a positive relationship between the capital/labor ratio and average wages (see Arai (2003)). In our model, this relationship depends on the technological assumptions about the relationship between quality and physical capital. A sufficient condition for quality and the capital/labor ratio to be positively related is $\gamma_{k} \leq \gamma_{E S}$ (to see this, just follow the argument used to obtain (11) and (12)). Under this condition, the capital/labor ratio would be positively associated with high average wages for every education level.
} 
important and increase in individual education. One implication of these results is that increasing globalization may tend to raise wage inequality within and across education groups.

The paper also builds a partial equilibrium model predicting a positive correlation at the firm level between firm size, output quality, number and remoteness of output markets, employees' average education, and wages within each education level. The model provides a potential explanation for all the empirical results in the paper, which is also consistent with an increasingly important strand of international trade literature. This literature emphasizes efficiency heterogeneity at the firm level and quality differentiation in describing the current patterns of international trade. Moreover, it has provided empirical support for a positive relationship between output-market remoteness and the quality of exports (which is an implication of the model that is not explored in the empirical part of this paper). Thus, the theoretical model coherently links the empirical results in the paper to some of the most recent trade literature.

Acknowledgments We thank two referees for their comments. A previous version of this paper circulated under the title "Firm Characteristics, Labor Sorting, and Wages". We acknowledge financial support from the Spanish Ministry of Education and Science under projects SEJ2005-07200 (PNICDI co financed by the FEDER), SEJ2005-08783-C04-02, and ECO2008-02654/ECON, and from Fundación Séneca de Murcia project 05710/PHCS/07. Part of this research was conducted while Francisco Alcalá was visiting the Economics Department at NYU.

\section{References}

Alcalá F, Hernández PJ (2006) Las externalidades del capital humano en la empresa española. Revista de Economía Aplicada 14:61-83

Arai M (2003) Wages, profits, and capital intensity: evidence from matched worker-firm data. J Labor Econ 21:593-618

Baker M, Fortin NM (2001) Occupational gender composition and wages in Canada, 1987-1988. Can J Econ 34:345-376

Baldwin R, Harrigan J (2007) Zeros, quality and space: trade theory and trade evidence. NBER working paper 13214, Cambridge

Battu H, Belfield CR, Sloane PJ (2003) Human capital spill-overs within the workplace. Oxford Bull Econ Stat 65:575-594

Bayard K, Troske KR (1999) Examining the employer-size wage premium in the manufacturing, retail trade, and service industries using employer-employee matched data. Am Econ Rev Papers Proc 89:99-103

Bernard AB, Jensen JB (1995) Exporters, jobs, and wages in US manufacturing: 1976-1987. Brookings papers on economic activity, Microeconomics, pp 67-119

Bernard AB, Jensen JB (1997) Exporters, skill upgrading, and the wage gap. J Int Econ 42:3-31

Bernard AB, Jensen JB (1999) Exceptional exporter performance: cause, effect, or both? J Int Econ 47:1-25

Bernard AB, Wagner J (1997) Exports and success in German manufacturing. Weltwirtschaftliches Archiv/Rev World Econ 133:134-157

Bernard AB, Jensen JB, Redding SJ, Schott PK (2007) Firms in international trade. J Econ Perspect 21:105-130

Biscourp P, Kramarz F (2007) Employment, skill structure and international trade: firm-level evidence for france. J Int Econ 72:22-51

Card D, De la Rica D (2006) The effect of firm-level contracts on the structure of wages: evidence from matched employer-employee data. Ind Labor Relat Rev 59:573-592 
Dolado JJ, Felgueroso F, Jimeno JF (2000) Youth labour markets in Spain: education, training, and crowding-out. Eur Econ Rev 44:943-956

Eaton J, Kortum S, Kramarz F (2004) Dissecting trade: firms, industries, and export destinations. Am Econ Rev Papers Proc 94:150-154

Eaton J, Kortum S, Kramarz F (2008) An anatomy of international trade: evidence from French firms. NBER working paper 14610

Falvey RE, Kierzkowski H (1987) Product quality, intra-industry trade and (Im) perfect competition. In: Kierzkowski H (ed) Protection and competition in international trade. Basil Blackwell, Oxford

Flam H, Helpman E (1987) Vertical product differentiation and North-South trade. Am Econ Rev 77:810-822

Fontagne L, Guillaume G, Zignago S (2008) Specialization across varieties and North-South competition. Econ Policy 23:51-91

Hallak JC, Sivadasan J (2008) Productivity, quality and exporting behavior under minimum quality requirements. Mimeo

Hummels D, Klenow P (2005) The variety and quality of a nation's exports. Am Econ Rev 95:704-723

Hummels D, Skiba A (2004) Shipping the good apples out? An empirical confirmation of the AlchianAllen conjecture. J Political Econ 112:1384-1402

Idson TL, Oi WY (1999) Workers are more productive in large firms. Am Econ Rev 89:104-108

Johnson RC (2007) Trade and prices with heterogeneous firms, mimeo, University of California-Berkeley

Khandelwal A (2007) The long and short (of) quality ladders, mimeo, Columbia University

Lallemand T, Plasman R, Rycx F (2005) The establishment-size wage premium: evidence from European countries. DULBEA working paper No 05-07.RS, Université Libre de Bruxelles

Manasse P, Turrini A (2001) Trade, wages, and superstars. J Int Econ 54:97-117

Maurin E, Thesmar D, Thoenig M (2002) Globalization and the demand for skill: an export based channel. CEPR discussion paper series No. 3406, London

Melitz MJ (2003) The impact of trade on intra-industry reallocations and aggregate industry productivity. Econometrica 71:1695-1725

Munch JR, Skaksen JR (2008) Human capital and wages in exporting firms. J Int Econ 75:363-372

Murphy KM, Shleifer A (1997) Quality and trade. J Dev Econ 53:1-15

Schank T, Schnabel C, Wagner J (2007) Do exporters really pay higher wages? First evidence from German linked employer-employee data. J Int Econ 72:52-74

Schank T, Schnabel C, Wagner J (2008) Higher wages in exporting firms: self-selection, export effect, or both? First evidence from German linked employer-employee data. IZA discussion paper 3359

Schott P (2004) Across-product versus within-product specialization in international trade. Quart J Econ 119:647-678

Stokey N (1991) The volume and composition of trade between rich and poor countries. Rev Econ Stud 58:63-80

Troske KR (1999) Evidence on the employer size-wage premium from worker-establishment matched data. Rev Econ Stat 81:15-26

Verhoogen EA (2008) Trade, quality upgrading and wage inequality in the mexican manufacturing sector. Quart J Econ 123:489-530

Yeaple S (2005) A simple model of firm heterogeneity, international trade, and wages. J Int Econ 65:1-20 